\title{
AESTHETIC AND SOCIAL COMMUNITY: MULTICULTURAL POETRY AND THE ANTHOLOGIZING OF POEMS
}

\author{
Yi-Hsuan Tso \\ National Taiwan Normal University
}

Scholars from various disciplines have explored the concept of multiculturalism from the perspectives of citizenship, recognition, representation, tokenism, constitutionalism, and other vantage points, with politics and education receiving most of the attention. ${ }^{1}$ While many efforts have been made to explore these aspects of multiculturalism, its significance in poetry, particularly in poetry's composition and critique, has not been duly taken into account. Multicultural poetry designates a critical abstraction in which poetry is classified by relation to a communal culture, history, or customs. In this definition, multicultural poetry is therefore inclusive of poetry written by ethnic minorities, women, nonmainstream religious practitioners, and members of other communities. To maintain a focus, this paper delimits its discussion to poetry's relationship with ethnicity and probes the interplay between aesthetic and ethnicity in three sections-Mainstream Poetry Anthologies: Tastes, Schools, and the Issue of History, Multicultural Poetry Anthologies: Situated Poetry and Group Poetics, and Ethnopoetics as a Choice.

The first two sections examine the standards of selection for poets represented in recent notable poetry anthologies and show how alternative canon formation can occur through the process of creating anthologies. The first section suggests that most mainstream poetry anthologies uphold editorial tastes and the schools of poetry as the chief criteria for culling poems. And yet, when minority editors joined in the selection of poems for these anthologies, they chose more poems about history and the material aspect of life. Next, in the second section, an examination of multicultural anthologies published since the mid-1990s yields instances illustrating that multicultural poetry is situated in its social, historical and cultural circumstances and is challenging the monism of the American identity, and that minority editors of poetry anthologies of specific ethnic

1 See Will Kymlicka's Multicultural Citizenship: A Liberal Theory of Minority Rights (1995), Charles Taylor's “The Politics of Recognition" in Multiculturalism: Examining The Politics of Recognition (1994), Charles Bernheimer's introduction, Gayatri Chakravorty Spivak's "Questions of Multiculturalism," and Stephen Tierney's Constitutional Law and National Pluralism (2004) (Bernheimer 8; Spivak 196-97). I gratefully acknowledge a grant from the National Science Council. 
groups recognize ethnicity as a shaping factor in the experience and selfexpression of ethnocultural communities. For example, Victor Hernández Cruz, Leroy V. Quintana, and Virgil Suarez acknowledge that poems in Paper Dance: 55 Latino Poets "focus on and are united by" particular "themes and perspectives" describing Latino experience (xii). Perusing these mainstream and multicultural poetry anthologies leads to the conclusion that aesthetic or taste is predicated upon external elements such as ethnicity and community rather than being a universal criterion of quality as editors of the mainstream anthologies maintain.

The final section deepens this discussion by undertaking a survey and critique of Asian American poetics. This exploration of the evolution of Asian American poetry criticism supplies examples in substantiating an argument that the choice of poetics is a choice of community in the cultural and historical sense. In other words, this paper suggests that ethnopoetics, or ethnic group poetics, is a choice of the literary and social communities engaged in artistic creation. This paper argues that multicultural poetry makes revolutionary changes to the definitions of "aesthetic" and of "poetry," changes which the poets find concerned with history, diversity, community, and other exigent ethnic issues. For reasons of space, discussion of the poetics of other ethnic groups is reserved for future research. Ultimately, this paper argues that ethnic poetry challenges the trend of universalism in forming aesthetics, anthologizing poetry, and fashioning poetics.

Emory Elliott argues in Aesthetics in a Multicultural Age that "the aesthetic is always in danger of being exploited in the service of individual prejudice or of nationalism, racism, sexism, and classism" (3). Elliott indicates that when one positions aesthetics in relation to one of these matrices, one opens up the polemic pertaining to the significance of aesthetic and, as this study will reveal, its functions with regard to canonization. As the examples will demonstrate, mainstream anthology editors' judgment manifests a common view of an aesthetic as a system of transcendent values justified by a tradition of cumulative standards of beauty as well as by editors' own private standards. However, tradition is entangled in the collective and the historical, whereas personal standards are imbricated with the individual and the present. This two-fold composition makes the division between the collective and the personal and between the historical and the present untenable. In other words, the social and historical situations of the critic will more likely than not be intermixed with their opinions.

Like Elliott, Giles Gunn reminds the reader that these two sets of qualities cannot be separated because taste originates in and is premised on communities: "[B]y being formed in relation with, and always in dialogue with, other people, taste . . not only presupposes community but 
actually generates it" (71). Likewise, Rita Dove suggests that ethnic poets adhere to something other than aesthetics when she discusses her twin foci of aesthetics and the author's circumstances in a 1989 interview: "First and foremost is just the language that is my clay and my primary interest. . . . But I am also positive that the fact that I am a woman, that I am black, that I am an American, and that I'm living in the time that I'm living in now has an enormous impact on my writing" (qtd. in Vendler 488). Elliott attributes the cause of this problematic to the superimposition of private taste on a collective agenda and the erasure of differences: "The critic in judgment who assumes that there are universal standards of beauty ... will be likely to erase or subordinate an array of human differences and forms of creative expression as being inferior to a select few" (3).

Analyzing universalism from a different angle of dialectics, David Palumbo-Liu maintains that minority literature underscores history and materiality while resisting the dominant culture, which "erases the contingencies of time and space, history and location" by assuming a "universal" value (188). The universalist rationale paradoxically advances while at the same time occludes the assimilation of minority culture:

Thus the contradiction is ... the fact that the Other invites the minority subject to identify itself within the dominant on the basis of its ideological interests. . . . This contradiction is precisely the mechanism which locates the minority subject in its liminal space. . . . [T]he hegemonic ... solicits the minor's consensuality as evidence of its [hegemonic] non-particularity, of its universality. ... And this is precisely the point at which, for my argument, the minor appears in the universal. (Palumbo-Liu 198-99)

One's aesthetic always already contains cultural connotations and communal practices. A just and more plausible assessment, as Sue-im Lee suggests, is therefore "a historically and materially engaged analysis" conjoined with the aesthetic as a critical perimeter (1).

\section{Mainstream Poetry Anthologies: Tastes, Schools, AND THE ISSUE OF History}

This section examines the standards of selection for poets represented in The Best American Poetry series published in the years 2000 to 2003. This series was launched by David Lehman in 1988 and annually publishes, in the judgment of its editors, the best poems currently written by Americans. Each guest editor is, by custom, an eminent poet, a new Poet Laureate, or a recent winner of the Pulitzer Prize for Poetry. There- 
fore, this series can be used to identify the directions that poetry is taking in a particular time period. The introductory section of each series and its selected poems serve as an index to the status quo of American poetry. It is reasonable to confine the research to the series volumes published over these four years because the year 2000 marks the point when ethnic poets were invited to be guest editors; Rita Dove took charge of the selection in 2000, and in 2003 Yusef Komunyakaa was guest editor. This section looks closely at why the editors favor some poets instead of others and some poems over others. After examining poems in this series published from 2000 to 2003, it is evident that ethnicity has a voice in aesthetics; it is not a coincidence that ethnic minority guest editors Dove and Komunyakaa both select more poems depicting historical moments or material circumstances, while the other two guest editors, Robert Hass and Robert Creeley, do not in their selections.

An equation of excellence with taste is implicit in Lehman's statement that The Best American Poetry anthologies "taken together chronicle the taste of some of our leading poets" (Foreword xiv). The editorial preferences of Lehman ensure that The Best American Poetry series habitually includes works written by poets of the New York School—John Ashbery, Frank O'Hara, Kenneth Koch, and James Schuyler (Last 1). The school took its name from the New York-based Abstract Expressionist painters, from whom these poets, three of whom were art critics, learned the models of the trajectories of thought (Lehman, Last 2-4, 46). This urban school, in Lehman's view, implements wit, humor, and irony through techniques ranging from juxtapositions, parodies, to collages (Last 4). ${ }^{2}$ Unsurprisingly, for example, from the year 2000 to 2003, poets of the New York School appear in all the anthologies except the 2000 anthology co-edited by Dove.

In addition to Lehman's predilections, the governing criteria of the series also shift to a certain extent each year to fit the guest editors' aesthetics (Foreword xiv). Dove, the first ever minority guest editor of the series, chose many poems for the 2000 anthology which register historical junctures or personal episodes, or fusions of the two experiences. For example, in Thomas Rabbitt's poem "The Beach at Falmouth Heights," the absence of the husband weaves with the loss of a brother in the Korean War. The poem, rooted in the historical event, is elegiacally filigreed in lines reminiscent of T. S. Eliot, albeit uttered by a female persona: "Each rose-scented day a perfect summer at the beach / Where the siren has no song to sing" is set in anticipation of a reconciliation in the mind of the speaker, who has "[s]till . . . / to settle for being when those we loved are gone" (Dove and Lehman 150). Likewise, Julianna

2 One of these poets, Koch, taught Lehman a life-changing writing class (Lehman, Last 233). 
Baggott melds the personal and the historical in the poem "Mary Todd on Her Deathbed" in which the female voice serves as a reminder of the weight of gender within historical events: "All the while" when guests mourned, and some stole from Lincoln's "open coffin" and in the White House, the guests "could hear" the First Lady "wailing from bed" (Dove and Lehman 33). Other poems coalescing personal and historical moments include "Aunt Lily and Frederick the Great" on the Jewish writer Moses Mendelssohn, "History \& Bikinis" on the uncle and the "irony" of history, and "Goldsboro Narratives" on the Vietnam War. Moreover, poems treating history account for a fifth of the poems in the anthology. For example, "The Last Living Castrato," "The Dump," "Epistle," "Ghosts," "Six Apologies, Lord," "The Goddess of Quotas Laments," "Henry Clay's Mouth," "I Do Not," "Pissarro at Dusk," and "Analysis of the Rose as Sentimental Despair" address historical topics.

Like Dove, the second minority editor of the series, Komunyakaa, prefers the historical and the personal content of a poem in compiling the 2003 anthology and argues that "content and aesthetics, with language as communication," are what makes poetry appealing to an audience (1819). The 2003 anthology includes seven poems on history, which is more than nine percent of all the poems selected. The poems in the 2003 edition explicitly about history include "Rambling on My Mind," "World History," "Some Rain," "When the Towers Fall," "A History of Color," "The Loaf," and "The Disappearances."

Remarkably, like Dove's edited anthology, Komunyakaa's collection does not feature any quintessential Language poems, which would be attentive to the conscious use of language such as language's "postreferential" prospect (Silliman 131). ${ }^{3}$ What could fittingly exemplify Komunyakaa's aesthetic of content is a poem in the collection, Stanley Moss's "A History of Color." "A History of Color" panegyrizes life's hybridity and multifariousness, a vibrance that helps humans withstand death, which the poem regards as a monistic state. The poem declares at the outset: "What is heaven but the history of color," color that pits its hybrid ("[h]arlot") and yet "sacred" vibrancy "against Death" (Komunyakaa and Lehman 125). This poem strings together anecdotes about colors addressing topics ranging from lust, religions, flora and fauna, rock, food, war, fabric, diseases, science, literature, paintings, and friendshipdetails echoing Komunyakaa's stress on materiality (Komunyakaa and Lehman 129).

By contrast, history and content are not as crucial to the guest editors of the 2001 and 2002 anthologies. For example, significantly lower than the number of poems Dove selected and still less than Komuny-

3 David Wojahn's "Scrabble with Matthews" unfolding in word play, and Billy Collins's "Litany" burlesquing the sonnet cannot really be called Language poems. 
akaa's choice, only five poems in the 2001 anthology edited by Hass deal with historical moments. Poems in the 2001 edition whose central concern is history or which treat history include "Crossed-Over, FiendSnitched, X-ed Out," "The Ashes," "To World War Two," "The Ghost Shirt," and "In Your Versions of Heaven I Am Younger."

Unlike Komunyakaa, who suggests a "synthesis" of content and "aesthetics," Hass argues for the otherworldliness of art and its detachment: "Art hardly ever does seem to come to us at first as something connected to our own world" (Komunyakaa 14; Twentieth 222). Abstractness is important to Hass, who, as his introduction makes clear, appreciates poems which attend to an idea and strike a balance between metrics, formal freedom, and experimentality: "I needed an idea" (Introduction 21); "the best work is often being done in the interstices between" "a metrical," a "free verse," and "an experimental tradition" in contemporary American poetry (Introduction 21). Thus, other than an obvious increase in poems treating the subjects of Eros and naturefavored topics of Hass's own poetry-the 2001 anthology consists of poems which experiment in form and etch memorable and humorous lines and endings. The abstractness Hass appreciates finds an apt exegesis in the poem "Night Picnic" by Charles Simic in which a woman lectures about God manifesting Himself in nature, while the poem's other character ponders the mystery of the unknown. A philosophical situation is created beneath the night sky, "[h]ome of every one of our dark thoughts," as this picnicker is "mulling over the particulars" of one's "cosmic significance" (Hass and Lehman 213). Moreover, the experimentality Hass values is illustrated in many poems. For example, Lyn Hejinian's poem "Nights," narrated in stanzas of irregular lengths, records the "ridiculous language" that the speaker hears in dreams (Hass and Lehman 107). For instance, Amy England's poem "The Art of the Snake Story" alternates snakes stories and discourses on storytelling techniques laid out formally like snakes (Hass and Lehman 76-81).

As in the 2001 anthology, history is not a prominent issue in the 2002 anthology, which Creeley guest edited. Creeley emphasizes poetry's constructedness, quoting William Carlos Williams ("A poem is a small (or large) machine made of words."), and maintains that poetry is "our imagining" of the world, or put in other words, "an act of figuring, of making a picture for ourselves of what it seems to be" (xviii, xxi). John Taggart's poem "Call," for example, portrays the emotions which surge after a consoling phone call ("a sort of resurfacing / coming up to the surface of what is not memory") rather than the content of the call: It is "not a matter of words" (Creeley and Lehman 165). As a result, in this anthology, only two poems- "TCAT serenade: 4498 (New Haven)" and "9-11-01"- -treat specific historical events. Moreover, in making the 
selection, Creeley favors poems which feature anacoluthons, intone a staccato voice, set up puzzles, and deploy white space to create a sense of mystery and silence. "Midsummer" and "Twenty-six Fragments" exemplify the effects of abstractness after dehistoricizing. In these four volumes of The Best American Poetry series, the universal view of poetry is inflected by Dove's and Komunyakaa's appreciation of the specificities of history and personal lives.

A subsuming of heterogeneous ethnic expressions under taste is also argued by a recent mainstream anthology, The Norton Anthology of Modern and Contemporary Poetry (2003). Like The Best American Poetry series, the anthology appeals to a single standard of excellence that judges poetry by inherent values equivalent to editorial tastes. However, the anthology has its own merits. Though this anthology does not venture the idea of ethnic aesthetics, it recognizes poetry as immersed in its world and implicated in its writing and critiquing community. The editor Jahan Ramazani, a Persian American, is more concerned with the effects of globalization "in our era of transnational imagination" than with ethnicity in representing the poets (Hybrid 184). Claiming that the evolution of poetry corresponds to a certain extent with shifts in "an increasingly transnational and cross-ethnic world," this anthology regards poetry as a global zone of exchange (Ramazani, Introduction lxvii). The anthology thus expands its selection of poetry from the customary English-speaking poets from the U.S., the U.K., Canada, and Australia to include poets from the Caribbean, Africa, and India.

\section{Multicultural Poetry Anthologies: Situated Poetry ANd Group Poetics}

Read alongside mainstream poetry anthologies, multicultural poetry anthologies such as Unsettling America: An Anthology of Contemporary Multicultural Poetry (1994) give evidence that in the imagination of ethnic poets, American poetry reinvents itself with regard to its diversity and definition. Unsettling America traces prevalent impulses and patterns in multicultural poetry. In this anthology, the term multicultural is defined as being different from the mainstream by one's "skin color, language, ethnicity" or "religion" (Gillan xx). The primary concern of Unsettling America is to "address the instability of American identity" as "a consequence of the complex intersections among peoples, cultures, and languages within national borders" (Gillan xix-xx). Implied in the title of the final section, this anthology foregrounds the right to define one's private, communal, and national cultural identities, an act which, the book's back cover summary suggests, could then dispel "myths and stereotypes" about these identities. 
Poems in this anthology are grouped under five descriptors- "Uprooting," which speaks of cultural disjunctions, "Performing," which examines media images, "Naming," which includes representations of experiences, "Negotiating," which explores bridges and divisions between the mainstream and minorities, and "Re-envisioning," which seeks the redefinition of Americanness (Gillan xx). Expressions of self-definitions vary from Joy Harjo's poem "I Give You Back" to Maria Mazziotti Gillan's poem "Growing Up Italian." "I Give You Back" explores the idea that expelling fears accrued from centuries of miseries is a precondition for the Native American speaker to reestablish an identity:

I take myself back, fear.

You are not my shadow any longer. (Gillan and Gillan 371)

In "Growing Up Italian," when the speaker, in her forties, realizes her internalized self-hatred, her longstanding regrets, silence, and feelings of inferiority "explode / onto paper like firecrackers" and "meteors," and she can now "take back" her "name" and "celebrate" her "Italian American self" through writing (Gillan and Gillan 384).

More recently, believing in the diversified origins of American imagination from ancient Tlingit Indian totem poles to Bessie Smith's lyrics, From Totems to Hip-Hop: A Multicultural Anthology of Poetry Across the Americas, 1900-2002 (2003) mints a new and broader literary lineage (Reed, Introduction xx). In the introduction, Bruce Allen Dick defines multiculturalism by its characteristics of "hybridity" and a panethnic "shared "Americanness" " (xxi). In this anthology, Reed adopts a method consisting of "[s]ynthesizing by combining elements like making a gumbo" and "[s]ynchronizing by putting disparate elements into the same time, making them run in the same time, together" (qtd. in Dick and Singh 53). Representing the hybrid nature of American literature, the anthology's poetry draws from folk legends and blues as well as hip-hop and slam rhythms for its inspiration: "American literature from the very beginning has been as mestizo as our hemisphere, influenced by a mixture of cultures, nations and races," Reed claims (Introduction xxix).

The compilation interweaves a wide spectrum of cultures and perspectives, resembling more closely the actual composition of society than mainstream anthologies. For instance, in the first section "Nature \& Place," Delhi, San José, Detroit, and other locales are connected with memory and feelings of people with diverse cultural heritages. For example, this link to places is memorably cast in Bessie Smith's "Black Mountain Blues" about this mountain range in North Carolina ("Black Mountains"): The female voice "[h]ad a man in Black Mountain[,] / the sweetest man in town" (Reed, From 70). Furthermore, acknowledging 
these "layers of cultural influence," From Totems to Hip-Hop features poetry dating back to approximately 1900 alongside contemporary works (Reed, Introduction xxv, xvii). The anthology limns a multifarious canon through thematic parallel arrangements of mainstream and ethnic poems, placing T. S. Eliot with Garrett Hongo and Robert Frost with Wendy Rose.

In the next two sections, "Men \& Women" and "Family," marriages and relatives acquire new dimensions when these occur in and across various cultures where Eliot's "maiden aunt" contrasts with Hongo's gambling father and Russell Leong's Chinese relatives (Reed, From 126). The fourth and fifth sections, "Politics" and "Heroes \& Sheroes, Anti \& Otherwise," set racial confrontations like hate crimes and cultural theft in the same section as historical issues like the Vietnam War, and popular legends like Duke Ellington and coyote folklore beside classical myths like Helen of Troy. Ultimately, the grouping into thematic sections structurally suggests a democratic leveling committed to presenting the poems on an equal footing. Most essays and poems-by Frank Chin et al., Lawrence Ferlinghetti, Geary Hobson, Carolyn Kizer, Alicia Suskin Ostriker, and Leslie Scalapino-in the closing "Manifestos" section also affirm this argument that confers authenticity and authority on experience grounded in culture (Reed, From 402, 407, 416-17, 425, 434, 439). For example, Ferlinghetti authenticates one's experience: "Listen says the sea" as "[w]ithin you" are "your private visions / of another reality" (Reed, From 407).

While multicultural poetry anthologies foreground common concerns such as heterogeneity, migration, and assimilation in ethnic minority poetry, poetry anthologies of single ethnic groups celebrate the distinct group aesthetics enmeshed in their histories, languages, and cultures. Multicultural anthologies of a specific ethnic group have the theoretical underpinning that poetry written from the perspective of a particular ethnic group has discrete qualities that make it Latino, African American, Asian American, and so on. For example, Paper Dance: 55 Latino Poets (1995) illuminates the primacy of multilingualism, acculturation, myths, gender, religions, and other issues in its poetry. The anthology's poems probe "the 'Americanization' process, the struggle to define, redefine, and attain the American Dream; the use of cultural myths; language and memory; gender; religion and spirituality"; "the question of universality and specificity," and so forth (Hernández Cruz, Quintana, and Suarez, Introduction xii).

For instance, two prominent themes in Paper Dance are brotherhood and multilingualism. Edna Acosta-Belin suggests that there exists "a shared consciousness . . . that transcends the specific national and cultural specificities of each group in favor of embracing a broad collec- 
tive [Latino] identity" (989). This idea of "brotherhood" is a common subject in Latino poetry. For example, Judith Ortiz Cofer's poem "The Latin Deli: An Ars Poetica" imparts this consciousness by portraying the poet as a benevolent matron giving her Latino readers- "Puerto Ricans," "Cubans," and "Mexicans" alike-the comfort of dreams about home (Hernández Cruz, Quintana and Suarez, Paper 26). This emphasis about brotherhood is foreshadowed at the very beginning by the Mother and Child magnet on the store owner's cash register (Hernández Cruz, Quintana, and Suarez, Paper 26). The customers feel "the comfort" through the "mix of smells" of food, language, and the very presence and demeanor of the store owner ("the family portrait / of her plain wide face, her ample bosom / resting on her plump arms, her look of maternal interest") (Hernández Cruz, Quintana and Suarez, Paper 26). Though the shop owner is informed of the needs of some of her Latino customers, for others' wishes she "must divine" and procure goods via her sympathetic imagination (Hernández Cruz, Quintana, and Suarez, Paper 27).

Another feature, multilingualism, is often presented by interpolating Spanish words or phrases and counterposing cultural viewpoints in the poetry. In Adrian Castro's poem "Herald of Cocos (I)," for instance, the contrasts between cities and barrios set of by a slash, and between the agricultural and industrialized islands ("islands vestid(o) in green / to islands of electric(o) steel") bespeak "dreams of migration" (Hernández Cruz, Quintana, and Suarez, Paper 18). Imagination shuttles between languages and lands in "a tango of speech," and in the United States, "many lips spell" this "message" of a group consciousness through Spanish loan words in everyday English (Hernández Cruz, Quintana, and Suarez, Paper 19).

Bearing a mission to disseminate a Black ideal, Spirit \& Flame: An Anthology of Contemporary African American Poetry (1997) punctuates the viability of the spirit of the Black community and the power in fury found in African American poetry of the 1990s (Gilyard, "Spirit" xix, xxii). The fury in the poetry of this anthology refers to the political undertone suggested by Keith Gilyard: "The overall tip is strongly political," which constitutes "the flame" in the poetry ("Spirit" xxii). The distinctive and strong political forums of poetry in this anthology range from daily encounters in American marketplaces and streets ("Theory on Extinction or what happened to the dinosaurs?") to the African diaspora ("Meanwhile, In Rwanda") and Afrocentricity ("Afrocentricity") (Gilyard, Spirit 11-12, 213-14, 288-89).

Moreover, the essence of this African American poetry is expressed in its rhythms transformed from jazz, hip-hop, rap, drum beats, and other music originating in African American culture. This aspect of African American poetry is akin to performance poetry in its valorization of 
sound and poet-audience rapport. For example, Karen Williams's poem "JAZZ (a new interpretation)" prizes equally meanings, sounds, and rhythms, describing jazz as "[e]uphony as brilliant as pomade on Nat Kings hair" as well as celebrating its vibrant concoctions of sound (Gilyard, Spirit 286). Through a fragment of an African American spiritual, the poem echoes the ruminations of Langston Hughes's "Weary Blues" and John Keats's "Ode to a Nightingale" on music's power to express and transport one's emotions:

Coming for to carry me

somewhere dark and always funky (Gilyard, Spirit 286)

The poem's myriad uses of alliteration, consonance, and onomatopoeia allude to the rising importance of sounds in today's African American poetry.

Still another anthology of poetry of a single ethnic group, Asian American Poetry: The Next Generation (2004), compounds the enduring tradition of ethnopoetics with generational disparity (Chang, Introduction xxvii). This anthology contends that second-generation Asian American poets write markedly less political, more mainstream, less lyrical, predominantly non-narrative, and more idiosyncratic poetry compared with the poetry in The Open Boat: Poems from Asian America (1993) (V. Chang, Introduction xviii, xxi). This assertion locates the impetus of this shift in the Asian American poets' expanded freedom to exercise choices such as form and suggests a variety of poetics-including mainstream and Asian American strains-regulating the poetry's tone, form, and aesthetic. Underlying this contestation is the notion that an Asian American poet could claim a poetic contingent upon a single cultural and literary community, as poets of the first generation did, or could straddle more than one of these communities in a literary crossover, as most secondgeneration poets demonstrate.

Compared to the poetry of first-generation poets in The Open Boat, second-generation Asian American poets in Victoria Chang's anthology write poetry more mainstream in subject matter. ${ }^{4}$ For example, as Victoria Chang indicates, love and gender are the centers around which innumerable poems revolve, while other poems capture the epiphanies about life and family (Introduction xviii). Registering specifically Asian American experience, some other poems portray ethnic culture as a mesmerizing influence. ${ }^{5}$ For instance, Vandana Khanna's poem "Spell" interprets

4 However, the mainstream aesthetic this anthology exhibits may not represent the young generation poets fully. Asian American Poetry noticeably does not celebrate forms championing sounds and music or more radical Language, performance, Hawaiian pidgin, or digital poems (J. Chang 210; Yu 228).

5 This experience is not "unmediated," as Adrienne McCormick warns that the marketing strategies of "many publishers" to sell Asian American literature as true accounts of ethnic 
the tenacious though flimsy connection of ethnic culture. In "Spell," on a trip to Agra, India, some descendants of Indian-American immigrants find themselves foreigners in their ancestral land: "We traveled the city like we didn't belong, a place I should call home / but as foreign to me as to you" (V. Chang, Asian 80). The variegated sensations of sounds and colors flocking around them in India illustrate this confounding and yet tenacious affiliation with India:

Then there were the stares, the calls to come look,

glass bangles shaken at us like charms, like some spell and it was, with garlands stringing the runway like tiny beads of blood.

\section{(V. Chang, Asian 81)}

Yet the second-generation Asian Americans search less for an attachment to the ancestral home than for a transcendent and almost magical idea of this place as Khanna's poem "The India of Postcards" adumbrates: "We were / looking for the gods, for the one thing / that shimmered more than silver, a pyramid / or temple, a country-something we couldn't fit / into our pockets" (V. Chang, Asian 81). One common topic of other poems is likewise the elusive yet abiding connection of ethnicity, seen in Suji Kwock Kim's poem "Montage with Neon, Bok Choi, Gasoline, Lovers \& Strangers," which cautions: "[Y]ou may never remember \& may you never forget" (V. Chang, Asian 91).

\section{Ethnopoetics as a Choice}

This criticism in Asian American Poetry culminates various incarnations of Asian American poetry criticism since the late 1980s, which sometimes accepts and other times distances itself from ethnopoetics, while fundamentally acknowledging it as a choice. My research then concludes that poetic is predicated in part upon which literary and cultural community acts as the poet's muse or audience. In 1987 Shirley Geok-lin Lim appropriated the term ethnopoetics to encompass Asian American poetry's stylistic, linguistic, and contextual uniqueness (5155). ${ }^{6}$ For Lim, "the chief denominator of the majority of" more than sixty

life may mislead the reader (125). Moreover, this position is complicated by the at once global and local characteristics of Asian American literature (Lim, Gamber, Sohn, and Valentino 16). McCormick suggests that an apposite position to appreciate Asian American literature would be a middle ground between poetry and ideology (151).

6 The word "ethnopoetic" was coined by Jerome Rothenberg in the year 1968, and its early significance is linked to the translation of Native American poetry into English in the journal Alcheringa: Ethnopoetics (Sherwood; "Statement"). Whetu Moanc: Contemporary Polynesian Poems in English (2003) collecting the works of poets living from Hawaii to New 
Asian American poetry collections, some "specialized anthologies as well as numerous magazines" that she perused "is the non-European character underlying their diverse styles, themes and forms" (52). Lim formulates the first level of ethnopoetics as being concerned with "surface features" such as "the choice of diction, figures of speech, imagery, and turns of phrases" (53). She defines the second "linguistic" level as represented by "the incorporation of phrases or whole lines of the original language," while she relates the third level to "intertextuality" (54$55)$.

Agreeing that ethnopoetics exists, but adding the feature of dynamism, recognizing that the poetics is always evolving, Chitra Divakaruni and Joseph Bruchac maintained in 1994 that formal and thematic similitude exists in Asian American poetry including its biculturalism, incompletely transmitted culture, narrative impulse, as well as the very state of Asian American poetry as a concept in flux:

There is so much more that gives Asian American poetry its distinct flavor. The way languages are blended with English, the rhythms of the original tongues shaping American speech. ... The feeling of being squeezed between two cultures ...., and the need to carve out a new identity. (Divakaruni 36)

Both storytelling and exploration of the complexities of family are characteristic of much Asian American writing. . . . [I]t is written by writers who, because of their Asian ancestry, have had the bicultural experience and point of view.... I think it ["Asian American poetry"] is constantly changing and being defined by every new voice heard. (Bruchac 45-46)

Without commenting about a group poetic, Sunn Shelley Wong in 2001, Zhuo Xiaojing in 2002, and Timothy Yu in 2006 emphasized Asian American poetry's affiliation with social history. In Kenneth Burke's theory, Wong defines Asian American poetry as the articulation of social conditions, while Zhuo analyzes the "fragmented" self in Marilyn Chin's poetry, which is written in "a new lyric mode" "rooted in the specific social and historical conditions of Asia Americans" (Wong 302; Zhuo 113). Yu extends Wong's view by suggesting the situatedness of the poetry not only in Asian American history but also in an emerging Asian American literary canon. Yu suggests that a "new, truly comprehensive anthology of Asian American poetry needed now would draw generously from" poetry written since the 1970s, "as well as offer notes and intro- 
ductions that place these aesthetics in their historical and literary contexts. But it would also offer a much longer historical perspective on Asian American poetry" (229).

Unlike Divakaruni and Bruchac, abrogating Lim's claim about a group poetic, both Garrett Hongo and David Mura in 1994 defined poetry more as a subjective and less as a social or collective activity (Hongo 5; Mura, "Where" 32). Hongo, for example, maintains that literature tells "primarily a subjective, even a dissident truth" (5). Mura's view regards ethnopoetics as a choice rather than a given in poetry and argues that Asian American poetry can be multiply defined. Mura in 1995 argues for the heteromorphism of poetry: Poetry "is indeed 'equipment for living,' but that living is a more complex task than our cultural constructions would make out" ("Margins" 182). Owing to the poetry's postmodern hybridity ("a postmodern sense of language"), Mura calls for the free adoption and recognition of both ethnic and mainstream poetics in Asian American poetry ("Margins" 180). Lee entertained the same view like Victoria Chang and Mura, demanding in 2006 for the construction of "a more multivalent critical vocabulary" to befit Asian American poetry's diversity (7). Like Mura, during a 2006 reading held in Taipei, Wing Tek Lum recognizes the range of poetics an Asian American poet could choose from and suggests that ethnopoetics for Asian American poets is a choice rather than a given. Analyzing the reasons for a choice of poetics, Josephine Foo maintains that the form of poetry is to a great extent determined by a poem's projected audience (12).

The analysis of mainstream and multicultural poetry anthologies suggests that ethnicity has significant bearing on the standards in anthologizing poetry. In a larger context, this questioning of a pure aesthetic detached from its social and cultural conditions is reflected earlier in the works of Pierre Bourdieu, who argues that "tastes" "function as markers of 'class'" "by a process of distinction" $(2,466)$. And in Bourdieu's analysis, "the theory of pure taste is grounded in an empirical social relation" with which distinction in society is established (490). Bourdieu suggests that the aesthetic is "inseparable from a specific cultural competence. . . . This mastery is, for the most part, acquired simply by contact with works of art" (4).

As the link between ethnicity and aesthetics cannot be gainsaid, the construction of critical concepts as well as criteria amenable to ethnicity is then requisite for measuring the intricacies of multiculturally inclusive American literature. In Ralph Ellison's words, Michael S. Harper and Anthony Walton suggest that "African American culture and its artifacts are not just of marginal but of central importance to the nation," and this view could apply to ethnic poetry in general (xxiv). Gilles Deleuze's analysis of minor literature also can apply to explain the innovative at- 
tributes of minority literature. Deleuze argues that "a minor practice of a major language," Prague German in the case of Franz Kafka, can be "revolutionary" within mainstream literature (153-55). For example, Kafka makes Prague German for "a creative utilization for the purposes of a new sobriety, a new expressivity, a new flexibility," and "a new intensity" (Deleuze 159). This understanding then offers a reconsideration of American poetry. The prevailing modes and the very idea of poetry cannot be isolated from the world and transcendent of literary and social communities, and therefore universal in terms of aesthetics. It can therefore be suggested that ethnic poetry and poetics elicit the reassessment of the aesthetic of poetry and the idea of social community in poetry.

\section{Works Cited}

Acosta-Belen, Edna. "Beyond Island Boundaries: Ethnicity, Gender, and Cultural Revitalization in Nuyorican Literature." Callaloo 15.4 (1992): 979-98. Print.

Bernheimer, Charles. "Introduction: The Anxiety of Comparison." Comparative Literature in the Age of Multiculturalism. Ed. Charles Bernheimer. Baltimore: Johns Hopkins UP, 1995. 1-17. Print.

"Black Mountains." Encyclopædia Britannica Online. Encyclopædia Britannica, 2011. Web. 2 May 2011.

Bourdieu, Pierre. Distinction: A Social Critique of the Judgment of Taste. Trans. Richard Nice. London: Routledge, 1996. Print.

Bruchac, Joseph. "Five Not So Easy Pieces." Amerasia Journal 20.3 (1994): 45-46. Print.

Chang, Juliana. Rev. of Asian American Poetry: The Next Generation. Amerasia Journal 31.3 (2005): 208-11. Print.

Chang, Victoria. Introduction. Asian American Poetry: The Next Generation. Ed. Victoria Chang. Urbana, IL: U of Illinois P. xv-xxx. Print.

- ed. Asian American Poetry: The Next Generation. Urbana, IL: U of Illinois P, 2004. Print.

Creeley, Robert. Introduction. The Best American Poetry 2002. Ed. Robert Creeley and David Lehman. New York: Scribner, 2002. xviixxii. Print.

Creeley, Robert and David Lehman, eds. The Best American Poetry 2002. New York: Scribner, 2002. Print.

Deleuze, Gilles. The Deleuze Reader. Ed. Constantin V. Boundas. New York: Columbia UP, 1993. Print. 
Dick, Bruce Allen. Introduction. The Critical Response to Ishmael Reed. Ed. Bruce Allen Dick. Critical Responses in Arts and Letters 31. Westport, CT: Greenwood,1999. xix-xxxix. Print.

Dick, Bruce, and Amritjit Singh, eds. Conversations with Ishmael Reed. Jackson, MS: UP of Mississippi, 1995. Print.

Divakaruni, Chitra. "A Distinct Flavor." Amerasia Journal 20.3 (1994): 35-36. Print.

Dove, Rita. Introduction. The Best American Poetry 2000. Ed. Rita Dove and David Lehman. New York: Scribner, 2000. 17-23. Print.

Dove, Rita and David Lehman, eds. The Best American Poetry 2000. New York: Scribner, 2000. Print.

Elliott, Emory. "Introduction: Cultural Diversity and the Problem of Aesthetics." Aesthetics in a Multicultural Age. Ed. Emory Elliott, Louis Freitas Caton, and Jeffrey Rhyne. New York: Oxford UP, 2002. 327. Print.

Foo, Josephine. "Poetry Chooses Her Listener." Amerasia Journal 20.3 (1994): 11-17. Print.

Foster, Lawrence, and Patricia Herzog, eds. Contemporary Philosophical Perspectives on Pluralism and Multiculturalism. Amherst, MA: U of Massachusetts P, 1994. Print.

Gillan, Jennifer. Introduction. Unsettling America: An Anthology of Contemporary Multicultural Poetry. Ed. Maria Mazziotti Gillan and Jennifer Gillan. New York: Penguin, 1994. xix-xxv. Print.

Gillan, Maria Mazziotti, and Jennifer Gillan, eds. Unsettling America: An Anthology of Contemporary Multicultural Poetry. New York: Penguin, 1994. Print.

Gilyard, Keith. "Spirit \& Flame/Birth \& Name." Spirit \& Flame: An Anthology of Contemporary African American Poetry. Ed. Keith Gilyard. 1st ed. Syracuse, NY: Syracuse UP, 1997. xix-xxii. Print.

- ed. Spirit \& Flame: An Anthology of Contemporary African American Poetry. 1st ed. Syracuse, NY: Syracuse UP, 1997. Print.

Gunn, Giles. "The Pragmatics of the Aesthetic." Aesthetics in a Multicultural Age. Ed. Emory Elliott, Louis Freitas Caton, and Jeffrey Rhyne. New York: Oxford UP, 2002. 61-77. Print.

Harper, Michael S. and Anthony Walton. Introduction. The Vintage Book of African American Poetry. Ed. Michael S. Harper and Anthony Walton. New York: Vintage, 2000. xxiii-xxxiii. Print.

Hass, Robert. Introduction. The Best American Poetry 2001. Ed. Robert Hass and David Lehman. New York: Scribner, 2001. 17-27. Print. 
Hass, Robert, and David Lehman, eds. The Best American Poetry 2001. New York: Scribner, 2001.

. Twentieth Century Pleasures: Prose on Poetry. 3rd ed. New York: Ecco, 1997. Print.

Hernández Cruz, Victor, Leroy V. Quintana, and Virgil Suarez. Introduction. Paper Dance: 55 Latino Poets. Ed. Victor Hernández Cruz, Leroy V. Quintana, and Virgil Suarez. New York: Persea, 1995. xixiii. Print.

Hernández Cruz, Victor, Leroy V. Quintana, and Virgil Suarez, eds. Paper Dance: 55 Latino Poets. New York: Persea, 1995. Print.

Hongo, Garrett. "Asian American Literature: Questions of Identity." Amerasia Journal 20.3 (1994): 1-8. Print.

Komunyakaa, Yusef. Introduction. The Best American Poetry 2003. Ed. Yusef Komunyakaa and David Lehman. New York: Scribner, 2003. 11-21. Print.

Komunyakaa, Yusef and David Lehman, eds. The Best American Poetry 2003. New York: Scribner, 2003. Print.

Lee, Sue-im. "Introduction: The Aesthetic in Asian American Literary Discourse." Literary Gestures: The Aesthetic in Asian American Writing. Ed. Rocío G. Davis and Sue-im Lee. Philadelphia: Temple UP, 2006. 1-14. Print.

Lehman, David. Foreword. The Best American Poetry 2002. Ed. Robert Creeley and David Lehman. New York: Scribner, 2002. ix-xv. Print. . The Last Avant-Garde: The Making of the New York School of Poets. New York: Anchor, 1998. Print.

Lim, Shirley Geok-lin. "Reconstructing Asian American Poetry: A Case for Ethnopoetics." MELUS 14.2 (Summer 1987): 51-63. Print.

Lim, Shirley Geok-lin, John Blair Gamber, Stephen Hong Sohn, and Gina Valentino. Introduction. Transnational Asian American Literature: Sites and Transits. Ed. Shirley Geok-lin Lim, John Blair Gamber, Stephen Hong Sohn, and Gina Valentino. Philadelphia: Temple U, 2006. 1-26. Print.

McCormick, Adrienne. "The Challenge of Asian American Poetry: Reading 'I' and 'Other' Persona Poems in Cathy Song and David Mura." Asian-American Writing: The Diasporic Imagination. Vol. 3. Theory, Poetry and the Performing Arts. Ed. Somdatta Mandal. New Delhi, India: Prestige, 2000. 122-55. Print.

Mura, David. "The Margins at the Center, the Center at the Margins: Acknowledging the Diversity of Asian American Poetry." Review- 
ing Asian America: Locating Diversity. Ed. Wendy L. Ng, et al. Association for Asian American Studies Ser. Pullman, WA: Washington State UP, 1995. 171-83. Print.

. "Where Are We and Where We're Going-a Brief Note." Amerasia Journal 20.3 (1994): 31-33. Print.

Palumbo-Liu, David. "Universalisms and Minority Culture." Differences: A Journal of Feminist Cultural Studies 7.1 (1995): 188-208. Print.

Ramazani, Jahan. Introduction. The Norton Anthology of Modern and Contemporary Poetry. Ed. Jahan Ramazani, Richard Ellmann, and Robert O'Clair. 3rd ed. Vol. 2. Contemporary Poetry. New York: W. W. Norton, 2003. xliii-lxvii. Print.

- The Hybrid Muse: Postcolonial Poetry in English. Chicago, IL: U of Chicago P, 2001. Print.

Reed, Ishmael. Introduction. From Totems to Hip-Hop: A Multicultural Anthology of Poetry Across the Americas, 1900-2002. Ed. Ishmael Reed. New York: Thunder's Mouth, 2003. xv-xxx. Print.

- ed. From Totems to Hip-Hop: A Multicultural Anthology of Poetry Across the Americas, 1900-2002. New York: Thunder's Mouth, 2003. Print.

Sherwood, Kenneth. "Ethnopoetics." The Facts on File Companion to 20-Century American Poetry. The Poetry Foundation. 2005. Web. 10 May 2011. Print.

Silliman, Ron. "Disappearance of the Word, Appearance of the World." The $L=A=N=G=U=A=G=E$ Book. Ed. Bruce Andrews and Charles Bernstein. Carbondale, IL: Southern Illinois UP, 1984. 121-32. Print.

Spivak, Gayatri Chakravorty and Sneja Gunew. "Questions of Multiculturalism." The Cultural Studies Reader. Ed. Simon During. New York: Routledge, 1993. 193-202. Print.

"Statement of Intention." Alcheringa Archive. Acheringa 1.1 (1970). Web. 7 May 2011.

Vendler, Helen. "An Interview with Rita Dove." Reading Black, Reading Feminist: A Critical Anthology. Ed. Henry Louis Gates, Jr. New York: Meridian, 1990. 481-91. Print.

Wendt, Albert, Reina Whaitiri, and Robert Sullivan. Introduction. Whetu Moana: Contemporary Polynesian Poems in English. Ed. Albert Wendt, Reina Whaitiri, and Robert Sullivan. Honolulu, HI: U of Hawai'i P, 2003. 1-3. Print. 
Wong, Sunn Shelley. "Sizing Up Asian American Poetry." A Resource Guide to Asian American Literature. Ed. Sau-ling Cynthia Wong and Stephen H. Sumida. New York: MLA, 2001. 285-308. Print.

Yu, Timothy. Rev. of Asian American Poetry: The Next Generation. Chicago Review 51.4 \& 52.1 (Spring 2006): 222-230. Print.

Zhuo, Xiaojing. "Marilyn Chin's Poetry of 'Self as Nation': Transforming the 'Lyric I,' Reinventing Cultural Inheritance." Asian American Literature in the International Context: Readings on Fiction, Poetry, and Performance. Ed. Rocío G. Davis and Sämi Ludwig. Contributions to Asian American Literary Studies. Vol. 1. Hamburg: LIT, 2002. 111-34. Print. 